\title{
Land policy in perspective
}

\author{
Nab Raj Subedi, Survey Officer \\ Survey Department, Nepal \\ subedi03939@itc.nl,nawraj_s@yahoo.com
}

\section{Keywords}

Land policy, land tenure security, land market, land taxation, land valuation, land use planning, land reform and land administration

\begin{abstract}
Fundamental entity where the existence resides is Land. Obviously being the basis of life and then source of wealth and power, land has been observed as a focal entity of social conflict and disorder. Any government willing to pay attention for good governance must give its eyes on the issues of land, otherwise, any effort made in the name of development will be like pouring water on sand. Being encapsulated by the strong but better political will for doing something to raise the people up from their plight and blight of abject poverty, it is urgently needed to formulate land policy whereby all policy implementation instruments will be systematically arranged within the skeleton of land policy framework. Land tenure security, land market, land valuation and taxation, land use planning and land reform are the main instruments envisaged in this paper ignoring which the expected gain out of the applied effort on any land issue can not meet the demand of the society. The block composed by these implementation instruments will rest on the system of land administration, acting as a tool designed to be matched with the land policy.
\end{abstract}

\section{Introduction}

One in five spends their life in urban slums. One in two lacks basic sanitation. Increasing numbers manage to trade rural for urban destitution (UN-HABITAT, 2004). FAO estimated that unless progress was accelerated, there could be some 680 million hungry people in the world by the year 2010, more than 250 million of whom would be in sub-Saharan Africa (World Food Summit, 1996). Until recently, majority of land surface under customary system were not recognized in Africa and therefore such area, on which rural people rely on for their livelihoods and subsistence, remained outside the realm of law. In parts of Asia, highly unequal ownership and access to asset have made it difficult to establish inclusive pattern of growth. In Eastern Europe, collective production structure have failed to contribute to rural growth (Deininger, 2003).In South America land reform is a major problem because enormous tracts of land are concentrated in very few hands with laborers no better off than serfs (Encyclopedia-Agrarian Reform). In Nepal, massive population is capturing the urban-fringe area as informal settlers. (Subedi and Paudyal, 2005).

From the discussion made above, it is seen that despite the social, economic and political importance attached to land, majority of countries seem lacking in formulating the land policy that brings the effective change. Directly or indirectly, these countries remain heavily dependent on land for the elemental needs of survival, for habitation, subsistence cropping.

To address all these issues, and more, it becomes imperative to bring in land policy. In fact, land administration strategies and process need to be structured within the broad policy framework, the shape of which will depend on the jurisdiction concerned. A common thread between the systems will be the promotion of the economic development, social justice and equity, political stability and environmentally sustainable development (Dale and McLaughlin, 2003). Land policy consists of the whole complex of legal and socio economic prescriptions that dictate how the land and the benefits from the land are to be allocated (UN Land Administration Guidelines, 1996). Deininger defines land policy as the rules governing access to and the distribution of the benefits from one of the economy's main assets. 
To materialize the essence of the land policy, different implementation instruments are required for which a well designed tool (from legal, institutional and technological perspective) i.e. a well designed land administration system is indispensable, which carries out fundamental activities such as recordation and maintenance of right (legal aspect), prepares cadastral index and other spatial information (map), disseminate relevant information to the required agencies or users. The form of the land administration system itself is dependent on which implementation instrument is emphasized on the land policy. To achieve these or to materialize what is prescribed as the land policy statement, different implementation instrument have been designed. Namely, those are land tenure security, land market, land taxation, land use planning, and land reform and the relationship between is shown in Figure 1. These are dealt in the subsequent sections.

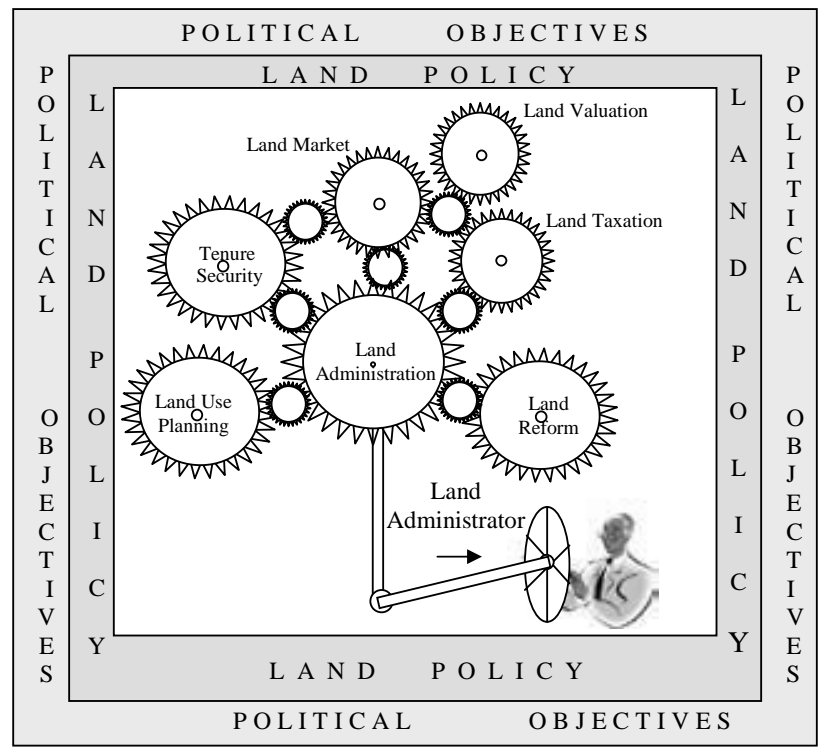

Figure 1: Showing the dependability of implementation instrument on the land administration tool and the systems encapsulated by land policy and ultimately by political objective

\section{Property rights and tenure security}

Land is a fundamental factor for agricultural production and is thus directly linked to food security. Without land, farmer can not grow, at least, their intended corps of production. If somebody is not assured of possession what he/she holds, then it constrains to perform development activities on that piece of land by the fear of possibility of eviction. Moreover the abiding law itself does not allow performing any economic activity (or/and use for benefit) on or with entity of non-ownership. People overwhelmed by the extreme poverty may be led to conflict and finally degrade the environment for short-term survival. Hence, from one perspective, security of land tenure implies economic development, environmental management, social stability, and can be supportive in reconstruction process following a disaster or conflict.

At the same time, it has been observed that property right assurance is not the only means of uplifting of poor. Property rights are only means of recognition by the authority and society. As long as informal occupation is not contested, user can use it for livelihood and agriculture production as it happens in the rural areas of mountain (in Nepal, the author has observed it) where people use unregistered land for horticulture or wild plantation of economic value. Another observation is that the highly complex formalities required for land titling causes the poor to enhance the hardship and make ultimately less attentive derailing them to be out of the system and making them informal settler.

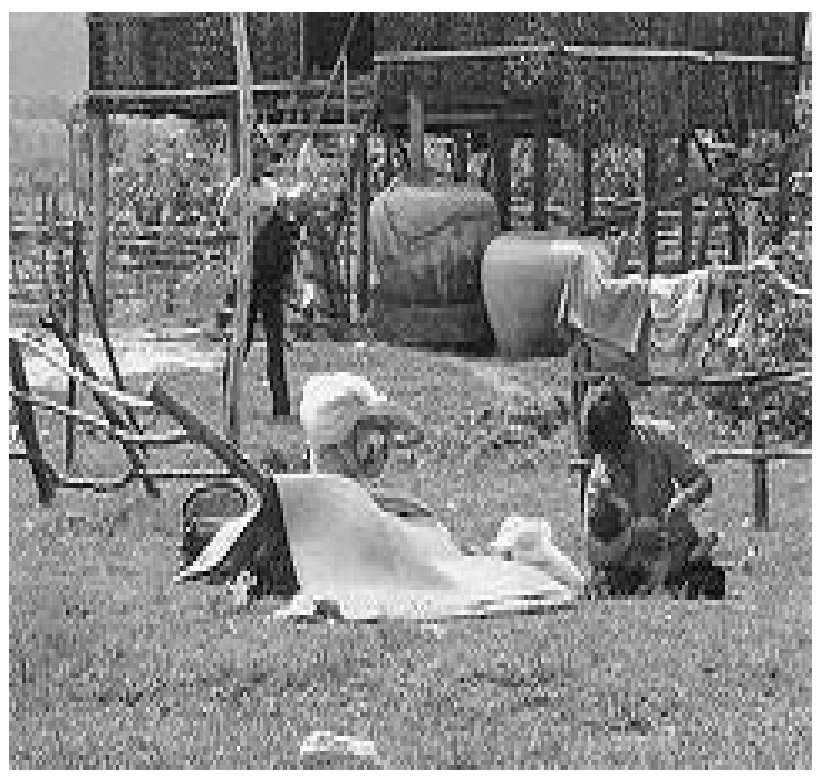

Figure 2, Evicted people under the open sky, Source: http://farm3.static.flickr.com

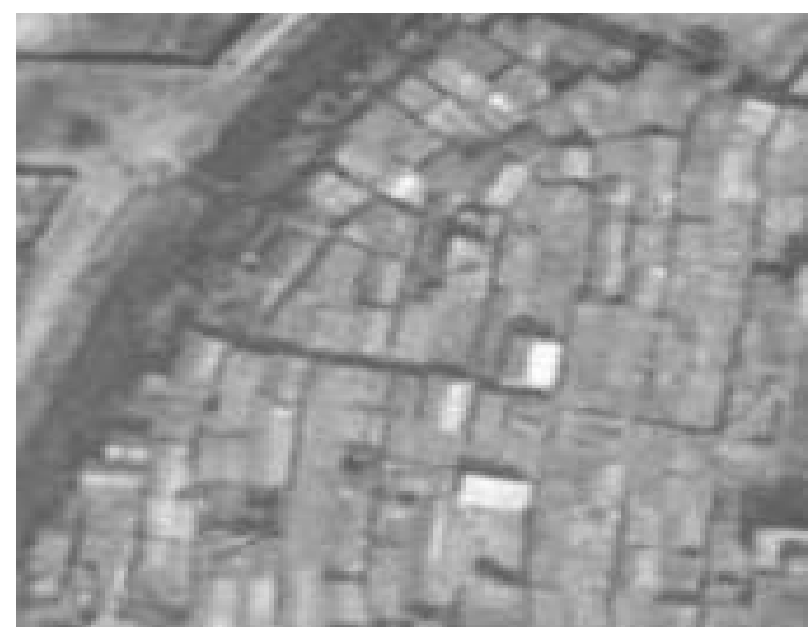

Figure 3, Informal settlement in Kapan 3, Kathmandu, Source: www.google.com 
In the other cases, property rights are related to the economic growth. Poorly defined land rights exploit the effort of the land holder just to defend their land and divert them from other income generating activities. Secure tenure rights facilitate transfer of rights at low transaction cost which stimulate formal land market and ultimately empowers the private sector (Deininger). Property rights itself should have some desirable characteristics which Land policy must hint for materialization of the expectation it states in its declaration.

- Mostly desirable one is the indefinite property rights, but if there are other rights (as described in the continuum such as lease or rental one), the accruable period must confirm the benefit from the land (or activities on it) over the investment. Hence such rights should be renewable and of long term and inheritable (so that widows or divorced can continue the economic performance).

- Property rights should be identifiable (depending up on the frequency of the transaction) and easily transferable (i.e. low transaction cost). There should also be provision of bundle of rights (stack of right sticks!) for different type of occupants.

- Since type of rights such as individual or group, is the matter of social, cultural and historical arrangement, such rights should be only ascertained based on (i) how the externalities can be managed (by group or by person), (ii) how the resources or outcome are to managed (iii) productivity (it is low if accrued by an individual effort and/or high if by the group force).This is more applicable to the agricultural land. (Figure 4 and 5)

- There must be presence or establishment of institutions for legal backings when legitimate or legal rights are to be enforced when called on by the property right holders (Deininger).

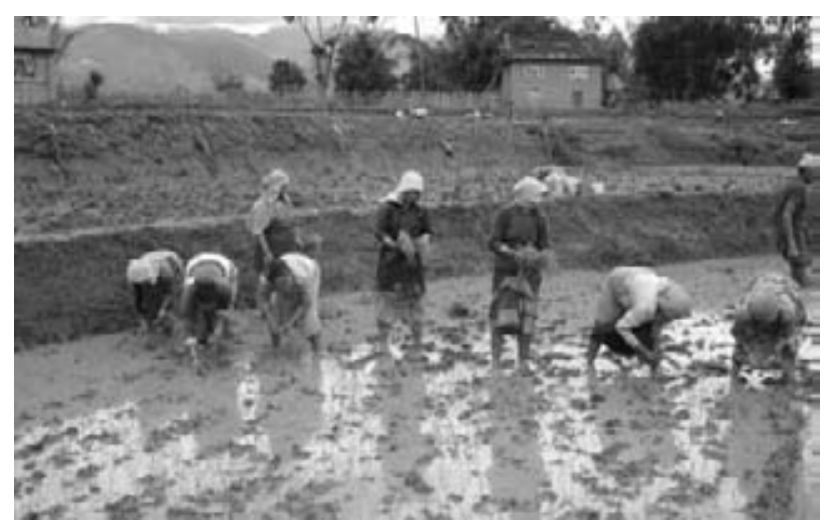

Figure 4, Showing group effort in cultivation

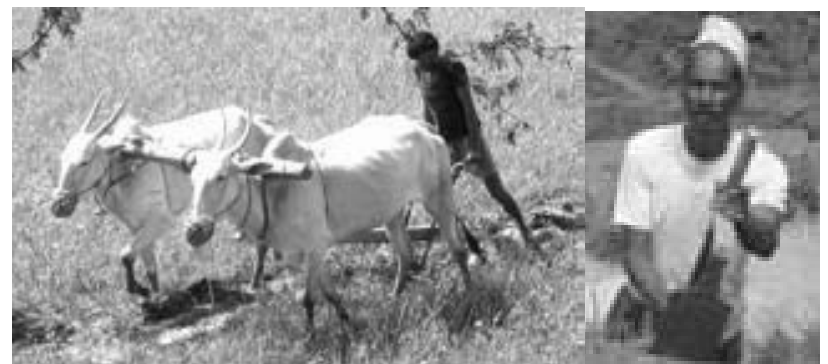

Figure 5, Individual effort with traditional technology may result low production.

- The land rights must be adaptable to the development i.e. it must be evolutionary that adapts the change carried by the technology. Particularly, in case of group rights which must be evolvable into the individual rights if an individual can generate the same or even more production than the group by the use of the state of art technology (Figure6).



Figure 6, Farming using technology

\section{Land policy and land market}

Land market is one of the formal mechanism that makes the land accessible to the poor (or rich as well). Different types of land market model such as sales market, rental market, and credit market and mortgage based on land are seen to be existing. But at the same time, land market may lead to destitution to the poor stripping them off their property, if there are speculations causing land accumulation by the so-called elites. In case of political turbulence or social unrest, people may not be able to sell their wage labor while they are compelled to sell their only piece of land by which they even lose their ultimate means of subsistence. Poor are easy to lure by money since they do not look for tomorrow. 


\subsection{Sales and rental land market}

The other facet of economics, macroeconomics takes the land as an element of factor market. In circular flow model, land acts as a base like labor and capital for firms. In sales market, land as an asset can be sold (in fact, only in psychological perspective we feel land as sold, in fact we only transfer the use right!) and as a result money can be generated. But depending on the use of land, the land is not generally purchasable by the poor or even if they purchase, the return against investment may not accrue due to market imperfection. In such situation, the accessibility to the land may be made by the rental system which needs less transaction cost or a mere agreement between the parties. Even in such rental market, the contract duration period should be flexible depending on the return (income) made out of the investment by the poor. The output to be provided to the real owner in rental land market may be based on sharecropping as a safeguard against market shocks because fixed cost may not be met if the production is low by some reason.

\subsection{Credit and Mortgage market}

Secure tenure is the basis of credit market. It acts as an incentive for investment to access credit by which landowner can either improve productivity of their land or generate income by selling the surplus or start microenterprise which makes them less-dependent on the wage labor (Figure 4, 5). Tenure security enhances the asset base of especially vulnerable groups such as women whose land rights are often neglected and improve the welfare of the poor. Non-farm owner can also keep their land as collateral in the financial institution and access credit by which they can make investment for off-farm activities. The risk factor in the mortgage market is that if an entrepreneur suffers bankruptcy due to economical shocks and can not gain what he expects out of the investment made, the deposit i.e. land asset subjects to moratorium after the terms of duration expressed in the contract.

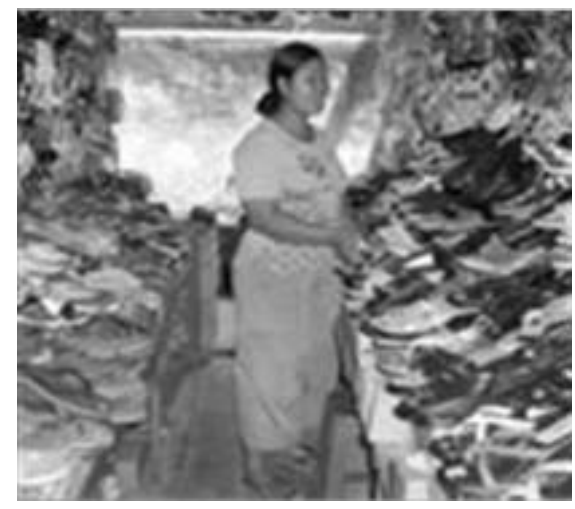

Figure 7

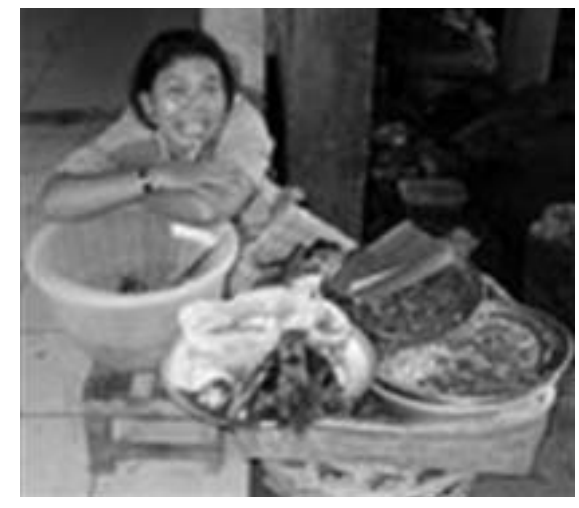

Figure 8

Example of micro-business by credit accessed from cooperatives Image source: www.idepfoundation.org/idep_microcredit.html

\subsection{Land market and Valuation}

Valuation is supposed as one of the pillar of land market like the land administration and financial sectors as long as land price is derived based on the land use (better say market derived) but not on the spatial extent. Land administration (LA) stimulates by providing the sense or perception of right to the actors. LA relates people and land by associating with the bundle of rights. Connection between the people and the money is done by the financial services such as bank, cooperatives but based on the rights on land. But the bridging between the land and monetary value is done by the valuation system. But the valuation must be based on the proper identification of the assets and should be carried out by one official body. Hence, land valuation has been shown as one of the cogs related connecting the land market (perception of the author of this report) in Figure 1.

Since land is an inelastic, immobile but tradable asset, it provides foundation for economic activity based on the transfer of rights (permanent or temporary). Activities on land can be more stimulated by establishing land market mechanism underpinned on the principle of tenure security. Land policy formulation process must not be oblivious of such potentiality and should be attentive for generating such market.

\section{Land policy and Land Taxation}

Taxation has both advantage and disadvantages from the economic, social and land use aspects. To make the people or landholder responsible and, at the same time, to generate a budgetary framework for the infrastructure development ( more generally for land use) in the local level, system of land taxation is indispensably essential but at the same time it distorts the land market pushing away 
the people from the formal land market. Tax exemption for lower value property is legitimate but it retards the money circulation in the market. Tax based on productivity is considered better as it calls on market parties but it induces competition which causes low revenue generation and retards the development activities of local government.

High taxation causes the people to run away from the formal system. Land taxation as well as land market mechanism can effectively sustain if there exists well defined and well designed land valuation system. Land market, land taxation and land valuation are separate system but in the modern perspective they are intertwined each other (Please refer Figure 1 above). The taxation system should also incorporate appeal procedure for those who do not get content on the tax imposed on their property.

\section{Land policy and Land use planning andpublic acquisition of land}

Land use and zone planning is the only land policy implementation instrument that ties land policy with other policies those concern for land. Land use planning synoptically deals with land generally from very small maps whereas cadastre deals with large scale maps. Expansion of agricultural land at the cost of the forest or other areas degrades environment. The story of urban area is also not seen promising. Exodus from rural to urban has caused urbanization to expand to the extent affecting the agrarian land turning into jungle of building for the purpose of housing, industrial or commercial set up. Land is accelerating toward scarcity. If it is not managed based on proper land use planning, over and haphazard exploitation will firstly deplete the public lands through grabbing and encroachment and then lead to social unrest or disintegration due to demands for shelter in the urban area which ultimately create social unrest due to the pressure of over population. It should not be forgotten that the value of the private land is judged by the quality of public space.

Lack of land use planning and its implementation cause the urban areas into slums. The more the public lands (green space, road, parks and river etc. but all managed) made availed through planning, the better the environment. The necessary of land zoning can be better illustrated by comparing the following two images of part of Kathmandu area (Source: www.Google.com)

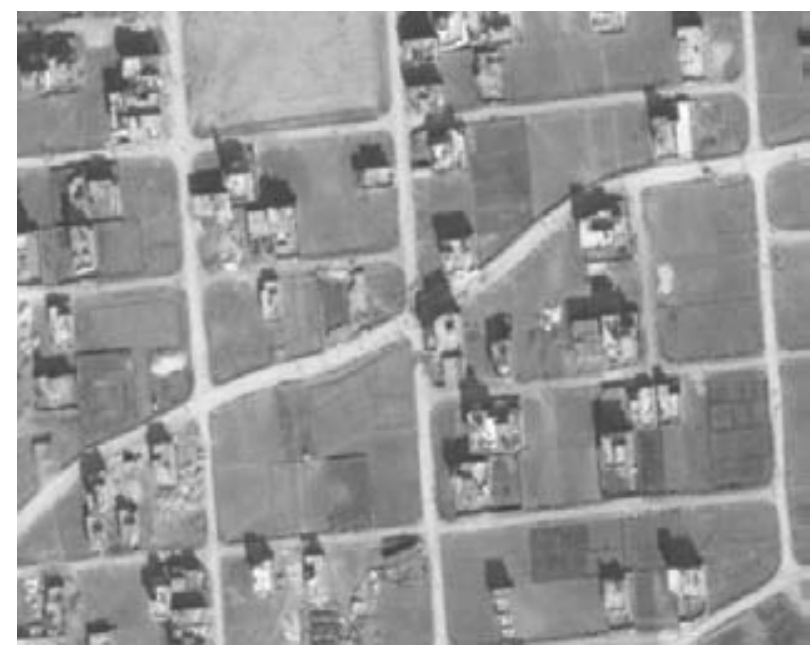

Figure 9, Town Planned area having secure land tenure in Sinamangal, Kathmandu

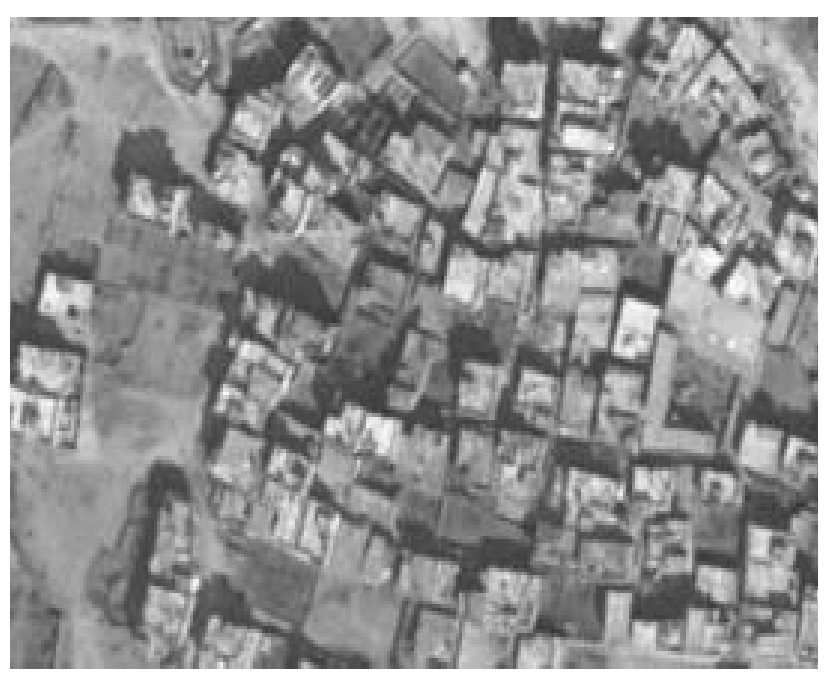

Figure 10, Unplanned area also having secure land tenure in Kapan, Kathmandu shows no road for the interior building

Access to land and Tenure security on the other hand is not the ultimate goal for better humankind. On one hand, people must be able to reap the benefit from the land they are given access to. On the other hand, in the name of accessibility to and ownership on land, they should not be authorized to generate side effect of the legitimate-use (!) in the environment (Figure 11). It means land accessibility for one should not violate the sustainability for the whole (society). It is here the concept of internalization of the externalities should be introduced just to balance the manland relationship by maintaining sustainable usability of land and its resources, through the legitimate restrictions which must be based on legislation and general interest. Controlling over exploitation and legitimate use entails land use planning. 
Land use regulation and zoning process involves creation of framework for planning, implementation and maintenance of the defined use, which by some way, always affect the owner in exercising their rights on use of the land. Therefore land use planning must be based on the standard multiple geo-spatial data of the area concerned by making use of national geospatial information infrastructure along with other socio-economic data. As mentioned above, it interferes with the private rights and therefore such measures must be based on the legal background and only for public welfare. Land policy must hint such issues so that expectation can be materialized. acquire credit. Government must arrange such mechanism. Properly formulated land reform program watchful to the side effect can solve national problem in stead of being a mere political agenda. Conspicuous example of land reform is Nicaragua's agrarian reform under the Sandinistas which resulted in expropriation of some large holdings(1979), which after initial collectivization has been progressively redistributed to individual farmers, including returning Contras after 1989(http://www.infoplease.com /ce6/sci/ A0856508.html).

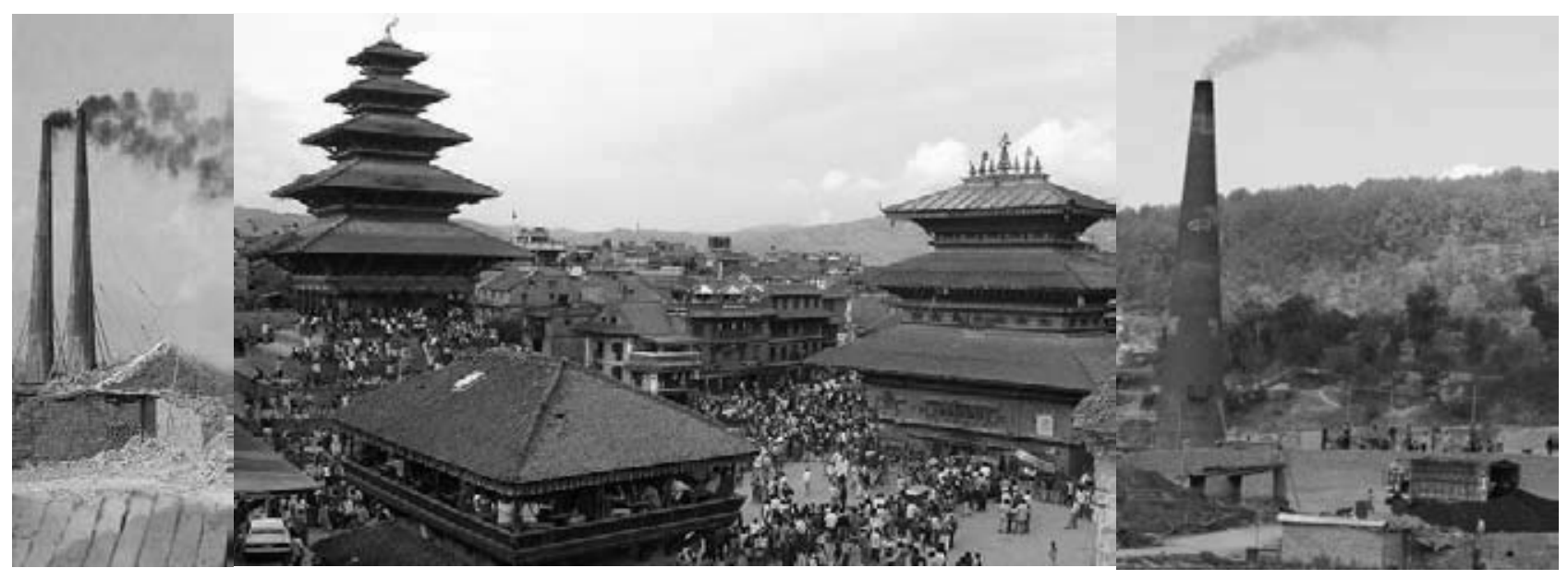

Figure 11 Using own land Clean Bhaktapur, having nasty polluters (brick kiln) surrounding and within the city, Nepal, (News source http://kantipuronline.com/kolnews.php?\&nid=59560)

\section{Land policy and Land Reform}

Land reform is the process of examining and changing laws, regulations and customs relating to land ownership and land tenure. The purpose of land reform should be to bring about a more equitable distribution of land ownership at the same time the land suffers underutilization adding to abject poverty on the rural people. This brings about access to land on the poor and also enhances agricultural productivity. Land reform program can take into many forms such as land redistribution, land tenure reform, land restitution, land consolidation etc. For implementation of such program, preventive legislation needs to be removed and new incentive legislation should be introduced. This usually involves changes in laws and regulations and also changes in customs.

The land reform as such does not bring an automatic the change on the economic status. For this, Poor must have accessibility to non-land assets and working capital by the poor. The beneficiary of land reform program must be able to

\section{Conclusion}

Land policy issues are highly complex having interrelation among them. It is related to an individual's subsistence to the whole society's welfare and only one sided orientation can not meet the multifaceted demands. Institutional responsibilities regarding land is not bound to only one sector but it comprises many of them such as environment, urban planning, agriculture, land reform etc, which necessitates to be threaded by broader policy framework and needs support and cooperation among all concerned line agencies.

Land administration is not itself a goal but it is meant to serve the policy implementation instruments. The form the administration is dependent of what the land policy declares or expects.

Guarantee of land tenure security, reduction of the transaction cost and environment for institutional enforcement for enjoy of accessed right are the preliminary issues the land policy should address to. Land policy 
issues are not unique and depend on the social, cultural and political and geographical setting of a particular country as well.

\section{References}

1. Bell K. C., 2007, Good Governance in Land Administration, Hong Kong

2. Dale P. and McLaughlin J., 1998, Land Administration, Oxford University Press, UK

3. Deininger K., 2003, Land Policies for Growth and Poverty Reduction, World Bank Report, USA

4. Encyclopedia, Agrarian Reform, Latin America and Africa, Columbia University Press, www. infoplease.com/ce6/sci/A0856508.html

5. EU Task Force on Land Tenure, 2004, EU Land Policy Guidelines

6. Holden S., Kaarhus R. and Lunduka R., 2006, Land Policy Reform: The Role of Land Markets and Women's Land Rights in Malawi
7. Istanbul Declaration on Human Settlements, 1996 , United Nations Conference on Human Settlements (Habitat II), Istanbul

8. Subedi N.R. and Paudyal D.R., 2005, Identification of Informal Settlement by Integration of Cadastral Information and Remote Sensing Satellite Imagery, www.oircf.org, FIG

9. UN-HABITAT, 2004, Pro Poor Land Management, UNHSP

10. United Nations, 2007, United Nations Land Administration Guide Lines, Reader, International Institute for Geo-information Science and Earth Observation, ITC, The Netherlands

11. van der Molen, P., 2008, Land Policy and Land Management, Reader, International Institute for Geo-information Science and Earth Observation, ITC, The Netherlands

12. World Food Summit, 1996, www.fao.org/wfs/ index_en.htm

\section{Participation in international events by the officials of Survey Department}

- $\quad$ Raja Ram Chhatkuli, the then Director General a.i.

- $\quad$ Tek Bahadur Shah, Chief Survey officer

RICS Asia Pacific Conference

3-7 July, 2008

Bangkok Thailand

- Professional education

Ganesh Prasad Bhatta, Chief Survey Officer

Janak Raj Joshi, Survey Officer

Roshani Sharma, Survey Officer

1 year from September 2008, ITC the Netherlands

- $\quad$ Raja Ram Chhatkuli, the then Director General a.i.

Public Land Management

7-13 September, 2008

Verona, Italy

- $\quad$ Raja Ram Chhatkuli, the then Director General a.i.

15th Asia Pacific Regional Space Agency Forum

8-12 December, 2008

Hanoi, Vietnam 